\title{
Comparative study on ammonia oxidation over Ni-based cermet anodes for Solid Oxide Fuel Cells
}

\author{
Ahmed Fathi Salem Molouk ${ }^{\text {a)}}$, Jun Yang a), Takeou Okanishi ${ }^{\text {a) }}$, Hiroki Muroyama ${ }^{\text {a) }}$, Toshiaki Matsui a), \\ and Koichi Eguchi ${ }^{\text {a), * }}$
}

a) Department of Energy and Hydrocarbon Chemistry, Graduate School of Engineering, Kyoto University, Kyoto 615-8510, Japan

${ }^{*}$ Correspondence should be addressed to

Koichi Eguchi

Department of Energy and Hydrocarbon Chemistry,

Graduate School of Engineering, Kyoto University,

Nishikyo-ku, Kyoto 615-8510, JAPAN

TEL: +81-75-383-2519, FAX: +81-75-383-2520

E-mail: eguchi@scl.kyoto-u.ac.jp 


\section{Abstract}

In the current work, we investigate the performance of solid oxide fuel cells (SOFCs) with $\mathrm{Ni}$-yttria-stabilized zirconia (Ni-YSZ) and $\mathrm{Ni}$-gadolinia-dope ceria (Ni-GDC) cermet anodes fueled with $\mathrm{H}_{2}$ or $\mathrm{NH}_{3}$ in terms of the catalytic activity of ammonia decomposition. The cermet of Ni-GDC shows higher catalytic activity for ammonia decomposition than Ni-YSZ. In response to this, the performance of direct $\mathrm{NH}_{3}$-fueled SOFC improved by using $\mathrm{Ni}-\mathrm{GDC}$ anode. Moreover, we observe further enhancement in the cell performance and the catalytic activity for ammonia decomposition with applying Ni-GDC anode synthesised by the glycine-nitrate combustion process. These results reveal that the high performance of $\mathrm{Ni}-\mathrm{GDC}$ anode for the direct $\mathrm{NH}_{3}-$ fueled SOFC results from its mixed ionic- electronic conductivity as well as high catalytic activity for ammonia decomposition.

Keywords: Direct $\mathrm{NH}_{3}-$ fueled SOFCs; ammonia decomposition; Ni-GDC; Ni-YSZ. 


\section{Introduction}

Increasing demand in electrical energy inevitably gives rise to the consumption of a large amount of fossil fuels and the emission of greenhouse gases to the environment. Solid oxide fuel cells (SOFCs) are electrochemical generators with high efficiency [1-4]. The performance of SOFC is dependent on the kind of fuel, anode materials, and anodic reactions. High performance can be achieved with hydrogen and hydrocarbon fuels. Hydrogen has been considered as a future clean fuel with the least emission of greenhouse gases $[5,6]$. However, the storage and transportation of hydrogen are major obstacles for the large-scale application due to its low volumetric density and boiling point $[7,8]$.

Recently, ammonia has attracted a great attention as a fuel because of many advantages; carbon free fuel with higher energy density, ease in liquefaction (boiling point: $-33.4^{\circ} \mathrm{C}$ at atmospheric pressure), and narrower flammable range than hydrogen, etc [9-13]. The worldwide distribution system is well established as widely produced commodity chemical and fertilizer. Based on these entire characteristics, ammonia, especially synthesized from the renewable energy, is considered as a future promising fuel and/or hydrogen carrier. Therefore, many studies were conducted in order to improve the performance of direct ammonia-fueled SOFCs using oxide-ion [14-18] or proton [19-23] conducting electrolytes.

Methane or natural gas has been considered as a suitable fuel for SOFCs because of its cleanliness among the fossil fuels and a higher energy density than hydrogen. However, its consumption 
inevitably accompanies $\mathrm{CO}_{2}$ emission. Our previous study indicated that the SOFC consisting of $\mathrm{Ni}-$ YSZ $\mid$ YSZ $\mid(\mathrm{La}, \mathrm{Sr}) \mathrm{MnO}_{3+\delta}$ demonstrated a higher performance with ammonia fuel than that with methane at the same temperature and anodic oxygen potential. The preferable performance of direct $\mathrm{NH}_{3}$-fueled SOFC resulted from a higher reactivity of $\mathrm{NH}_{3}$ for decomposition than $\mathrm{CH}_{4}$ reforming on $\mathrm{Ni}-\mathrm{YSZ}$ [24].

The Ni-YSZ cermet is the most popular anode material, which achieves most of the requirements for efficient SOFCs [25-27]. However, the activity of Ni-YSZ anode for the electrochemical oxidation of fuels such as hydrocarbon and ammonia is often insufficient $[28,29]$. On the other hand, gadolinia-doped ceria (GDC) has several advantages to YSZ as an oxide component for the cermet anode. GDC is a mixed ionic-electronic conductor under reducing atmospheres and its ionic conductivity is higher than that of YSZ [29]. Ceria has been known not only as a mixed conductor but also a catalyst material for oxidation-reduction reactions. Ceria also serves as a support for the $\mathrm{Ni}$ catalyst and prevents from sintering to provide a large and active triple-phase boundary (TPB) [3032].

In this work a comparative study on Ni-YSZ and Ni-GDC cermet anodes for SOFCs using $\mathrm{H}_{2}$ and $\mathrm{NH}_{3}$ fuels was conducted. We focused on the evaluation of the catalytic activity of Ni-YSZ and $\mathrm{Ni}-\mathrm{GDC}$ for $\mathrm{NH}_{3}$ decomposition and the polarization resistance of each anode. The effect of preparation method of $\mathrm{NiO}-\mathrm{GDC}$ on $\mathrm{NH}_{3}$ decomposition reaction was also studied for the development of active anode for direct $\mathrm{NH}_{3}-$ fueled SOFCs. 


\section{Experimental}

Electrolyte supported cells were used for the performance evaluation. Two different Ni-based cermet anodes (Ni-YSZ and Ni-GDC) were prepared. The NiO-YSZ anode powder was prepared by the physical mixing route as described elsewhere [24]. On the other hand, NiO-GDC anode powder was prepared by two methods; i) physical mixing and ii) glycine-nitrate combustion routes. The schematic diagram of the preparation routes is shown in Fig. 1. The physical mixing was carried out by ball-milling of $\mathrm{NiO}$ (Wako Pure Chemical Industries), GDC $\left(\mathrm{Ce}_{0.9} \mathrm{Gd}_{0.1} \mathrm{O}_{1.95}\right.$, Shin-Etsu Chemical Co.), and $10 \mathrm{wt} . \%$ carbon black as a pore former in ethanol for $24 \mathrm{~h}$. The powder from the physical mixing is denoted as NiO-GDC (PM). For the glycine-nitrate combustion route, stoichiometric amounts of $\mathrm{Ce}\left(\mathrm{NO}_{3}\right)_{3} \cdot 6 \mathrm{H}_{2} \mathrm{O}$ (Wako Pure Chemical Industries), $\mathrm{Gd}\left(\mathrm{NO}_{3}\right)_{3} \cdot 6 \mathrm{H}_{2} \mathrm{O}$ (Wako Pure Chemical Industries), and $\mathrm{Ni}\left(\mathrm{NO}_{3}\right)_{3} \cdot 6 \mathrm{H}_{2} \mathrm{O}$ (Wako Pure Chemical Industries) were dissolved in water with stirring at room temperature. Glycine (Wako Pure Chemical Industries) was then added to the solution until the molar ratio of total metal ions/glycine reached to $1 / 2$. After complete drying, the self-ignition takes place at $c a .350^{\circ} \mathrm{C}$. The obtained ash was calcined at $850^{\circ} \mathrm{C}$ in air for $5 \mathrm{~h}$. The resultant powder was mixed with $10 \mathrm{wt} . \%$ carbon black as a pore former and ball-milled in ethanol for $24 \mathrm{~h}$. The powder thus prepared is abbreviated as $\mathrm{NiO}-\mathrm{GDC}(\mathrm{GN})$. The Ni metal content in the anode was 60 wt. $\%$ after reduction treatment at $1000^{\circ} \mathrm{C}$ for every Ni-oxide cermet. The perovskite type oxide of $\left(\mathrm{La}_{0.8} \mathrm{Sr}_{0.2}\right)_{0.97} \mathrm{MnO}_{3}$ (LSM) was selected as a cathode and prepared as was reported earlier [33]. The 
obtained anode and LSM powders were mixed with polyethyleneglycol (PEG, Wako Pure Chemical Industries) to form slurry.

Cells were fabricated by screen printing the anode slurry on the flat face of YSZ disk electrolyte (8 mol\% yttria-stabilized zirconia electrolyte, Tosoh, $500 \mu \mathrm{m}$ in thickness and $24 \mathrm{~mm}$ in diameter) and firing at $1400^{\circ} \mathrm{C}$ in air for $5 \mathrm{~h}$. Then, the cathode was printed and fired at $1150^{\circ} \mathrm{C}$ in air for $5 \mathrm{~h}$. The electrode active area was $0.28 \mathrm{~cm}^{2}$ and the thicknesses were $60 \mu \mathrm{m}$ and $40 \mu \mathrm{m}$ for anode and cathode, respectively. A platinum reference electrode was fixed by the platinum paste (Metalor Technologies (Japan) Corp.) around the edge of YSZ disk and fired at $900^{\circ} \mathrm{C}$ in air for $2 \mathrm{~h}$. Finally, the cell was set between two alumina tubes and sealed by Pyrex glass rings to avoid the gas leakage.

The anode was reduced at $1000^{\circ} \mathrm{C}$ for $1 \mathrm{~h}$ prior to the electrochemical test. The anode gas mixtures were $\mathrm{H}_{2}-\mathrm{H}_{2} \mathrm{O}-\mathrm{Ar}$ and $\mathrm{NH}_{3}-\mathrm{H}_{2} \mathrm{O}-\mathrm{Ar}$. The gas composition of $\mathrm{NH}_{3}-\mathrm{H}_{2} \mathrm{O}-\mathrm{Ar}$ was controlled to achieve the same hydrogen concentration and flow rate of $\mathrm{H}_{2}-\mathrm{H}_{2} \mathrm{O}-\mathrm{Ar}$ when the complete decomposition of ammonia occurred. The cathode gas was $100 \% \mathrm{O}_{2}$ with a total flow rate of $100 \mathrm{ml} \mathrm{min} \mathrm{m}^{-1}$. Electrochemical measurements were carried out by the CellTest system (Solartron Analytical, potentiostat/galvanostat $1470 \mathrm{E}$ and frequency response analyzer 1455A). After power generation test in hydrogen and ammonia fuels the anode microstructure was observed by a scanning electron microscopy (SEM, Nvision 40, Carl Zeiss-SIINT).

The catalytic activity for $\mathrm{NH}_{3}$ decomposition over Ni-YSZ, Ni-GDC (PM), Ni-GDC (GN), YSZ, and GDC was studied using a fixed bed reactor. In these measurements, all samples were pre-calcined 
at $1400^{\circ} \mathrm{C}$ for $5 \mathrm{~h}$ in air and then ball-milled in ethanol overnight. All powders were pressed into a pellet at $20 \mathrm{MPa}$ and then pulverized to 12 mesh. The sample $(0.6 \mathrm{~g})$ was set in a fixed bed reactor and then reduced in $\mathrm{H}_{2}-\mathrm{Ar}$ at $700^{\circ} \mathrm{C}$ for $1 \mathrm{~h}$. After that the temperature was reduced to $350^{\circ} \mathrm{C}$ within $1 \mathrm{~h}$ in hydrogen, and then the reactor was purged with $\operatorname{Ar}\left(50 \mathrm{ml} \mathrm{min}^{-1} \mathrm{Ar}\right.$ for $\left.30 \mathrm{~min}\right)$. The reactant gas of $66.7 \% \mathrm{NH}_{3}-33.3 \% \mathrm{Ar}$ (total flow rate; $60 \mathrm{ml} \mathrm{min}^{-1}$ ) was supplied to each catalyst with a space velocity of $60001 \mathrm{~kg}^{-1} \mathrm{~h}^{-1}$. The outlet gas was passed through two traps containing $3.5 \mathrm{M} \mathrm{H}_{2} \mathrm{SO}_{4}$ solution (Wako Pure Chemical Industries) to dissolve the unreacted $\mathrm{NH}_{3}$ and then the flow rate of outlet gas containing $\mathrm{H}_{2}-\mathrm{N}_{2}-$ Ar was measured by using a flow rate meter (VP3, Horiba STEC Co, Ltd.). The percentage of $\mathrm{NH}_{3}$ decomposition can be calculated using Eq. (1).

$\mathrm{NH}_{3}$ decomposition $/ \%=\left(\frac{F\left(\mathrm{NH}_{3} \text { inlet }\right)-F\left(\mathrm{NH}_{3} \text { unreacted }\right)}{F\left(\mathrm{NH}_{3} \text { inlet }\right)}\right) \times 100$

where $F\left(\mathrm{NH}_{3}\right.$ inlet $)$ and $F\left(\mathrm{NH}_{3}\right.$ unreacted) are the flow rate of ammonia in the inlet gas and unreacted ammonia in the outlet gas, respectively.

The surface basicity of YSZ and GDC was also measured by the temperature-programmed desorption of carbon dioxide ( $\mathrm{CO}_{2}$-TPD) using BELCAT-B (BEL Japan, Inc.). The samples were preheated at $1400^{\circ} \mathrm{C}$ in air for $5 \mathrm{~h}$ and then ball-milled in ethanol overnight. The resultant powder was pressed into a pellet as in the catalyst test. Prior to the TPD experiment, $1 \mathrm{~g}$ of the sample was pre-treated in a helium atmosphere at $600^{\circ} \mathrm{C}$ for $1 \mathrm{~h}$ and then cooled to $50^{\circ} \mathrm{C}$. Carbon dioxide was 
supplied with a flow rate of $30 \mathrm{ml} \mathrm{min}{ }^{-1}$ for $1 \mathrm{~h}$. After the sample was purged with helium at $50^{\circ} \mathrm{C}$ for $0.5 \mathrm{~h}$, the sample was heated to $900^{\circ} \mathrm{C}$ at a heating rate of $10^{\circ} \mathrm{C} \mathrm{min}^{-1}$ to monitor desorption of $\mathrm{CO}_{2}$ using an on-line mass spectrometer (Pfeiffer Vacuum, OmniStare GSD320).

The specific surface area was determined by $\mathrm{N}_{2}$ adsorption-desorption with the BET method at $-196^{\circ} \mathrm{C}$ using BELSORP-miniII (BEL Japan, Inc.) The anode cermets were preheated at $1400^{\circ} \mathrm{C}$ for 5 $\mathrm{h}$ in air and then reduced at $1000^{\circ} \mathrm{C}$ in hydrogen. Prior to the BET experiment, $0.1 \mathrm{~g}$ of the sample was heated at $300^{\circ} \mathrm{C}$ in vaccum.

\section{Results and discussion}

3.1 Catalytic activity of $\mathrm{Ni}$-based cermet for ammonia decomposition

In the previous studies, it was suggested that the consumption of ammonia fuel proceeds via the two step reaction over Ni-based electrodes in SOFCs [11, 24, and 34]. Ammonia decomposes over the $\mathrm{Ni}$-based cermet to $\mathrm{H}_{2}$ and $\mathrm{N}_{2}$ by the thermal catalytic reaction followed by the electrochemical hydrogen oxidation. Therefore, the catalytic activity of Ni-based cermet for ammonia decomposition is one of the key factors to develop high performance anodes for direct $\mathrm{NH}_{3}$-fueled SOFCs. In this study, the catalytic activities for ammonia decomposition over Ni-YSZ, Ni-GDC (PM), YSZ, and GDC were investigated using a fixed bed reactor. The Ni-GDC (PM) cermet demonstrated the highest activity for ammonia decomposition at $600^{\circ} \mathrm{C}$ among the catalysts tested (see Fig. 2(a)). Though Ni metal was indispensable for sufficient activity, GDC exhibited the catalytic activity to some extent 
compared with YSZ which was inactive for the ammonia decomposition. It is expected that activity of $\mathrm{Ni}$ metal was further promoted by coexisting GDC because of the chemical interaction between $\mathrm{Ni}$ and GDC.

The catalytic decomposition of ammonia is composed of several reaction steps, i.e., i) adsorption of ammonia onto catalyst sites, ii) cleavage of N-H bond of adsorbed ammonia, and iii) desorption of $\mathrm{N}_{2}$ molecules. Generally, the last two steps control the rate of overall reaction [35-37]. The basic sites on the catalyst surface play an important role for promoting the rate determining step to achieve higher ammonia conversion $[38,39]$. Therefore, $\mathrm{CO}_{2}-\mathrm{TPD}$ experiment was conducted to YSZ and GDC. In the $\mathrm{CO}_{2}-\mathrm{TPD}$ profiles in Fig. 2(b), three peaks of $\mathrm{CO}_{2}$ desorption were observed for GDC at ca. $120^{\circ} \mathrm{C}, 210^{\circ} \mathrm{C}$, and $683^{\circ} \mathrm{C}$. On the other hand, only two $\mathrm{CO}_{2}$ desorption peaks were confirmed for YSZ at $c a .127^{\circ} \mathrm{C}$, and $675^{\circ} \mathrm{C}$. These results suggest that both oxides have weak and strong basic sites. The total amount of $\mathrm{CO}_{2}$ desorbed from YSZ and GDC were $4.5 \mu \mathrm{mol} \mathrm{g} \mathrm{g}^{-1}$ and $42.7 \mu \mathrm{mol} \mathrm{g} \mathrm{g}^{-1}$, respectively. Thus, it can be considered that the basic sites are abundant on the surface of the Ni-GDC (PM) cermet. Such a surface basicity is expected to be favorable for weakened adsorption of $\mathrm{NH}_{3}$ and dissociation of $\mathrm{N}-\mathrm{H}$ bond. On the other hand, it was proven that the hydrogen has a retardant effect for both $\mathrm{Ni}-\mathrm{YSZ}$ and $\mathrm{Ni}-\mathrm{GDC}$ anodes blew $800^{\circ} \mathrm{C}[24,40]$, and the rate of ammonia decomposition reaction depends on ammonia and hydrogen partial pressure according to the following equation;

$$
r_{\mathrm{NH}_{3}}=k P\left(\mathrm{NH}_{3}\right)^{\alpha} P\left(\mathrm{H}_{2}\right)^{\beta}
$$


where $r_{N H 3}$ is the rate of ammonia decomposition reaction, $P\left(\mathrm{NH}_{3}\right)$ and $P\left(\mathrm{H}_{2}\right)$ are the partial pressure of ammonia and hydrogen, respectively, $k$, $\alpha$, and $\beta$ are constants. The values of $\beta$ at $500^{\circ} \mathrm{C}$ for $\mathrm{Ni}-\mathrm{YSZ}$ and Ni-GDC were -0.94 and -0.81 , respectively [40]. This indicates that the retardant effect of hydrogen is less significant on the Ni-GDC (PM).

\subsection{Electrochemical properties and fuel cell characteristics}

Electrochemical impedance spectroscopy was carried out under the open circuit condition for the fuel cells employing the Ni-YSZ and Ni-GDC (PM) anodes with supplying $60 \% \mathrm{H}_{2}-0.5 \%$ $\mathrm{H}_{2} \mathrm{O}-39.5 \%$ Ar (flow rate; $100 \mathrm{ml} \mathrm{min}^{-1}$ ) and $66.7 \% \mathrm{NH}_{3}-0.8 \% \mathrm{H}_{2} \mathrm{O}-32.5 \%$ Ar (flow rate; $60 \mathrm{ml}$ $\min ^{-1}$ ). The impedance spectra of anodes in wet $\mathrm{H}_{2}$ and $\mathrm{NH}_{3}$ at $600^{\circ} \mathrm{C}$ and $1000^{\circ} \mathrm{C}$ are shown in Fig. 3(a-d). The anodic polarization resistance for Ni-GDC (PM) was smaller than that for Ni-YSZ both in wet $\mathrm{H}_{2}$ and $\mathrm{NH}_{3}$ fuels regardless of temperature. The polarization resistances in hydrogen and ammonia were almost the same for the respective anode at $1000^{\circ} \mathrm{C}$. On the other hand, the polarization resistance in ammonia was larger than in hydrogen for both anodes at $600^{\circ} \mathrm{C}$.

The temperature dependence of the anodic polarization resistance for two anodes in wet $\mathrm{H}_{2}$ and $\mathrm{NH}_{3}$ fuels at $600-1000^{\circ} \mathrm{C}$ was summarised in Fig. 3(e) and (f). The polarization resistance of Ni-YSZ in $\mathrm{H}_{2}$ was larger than that of $\mathrm{Ni}-\mathrm{GDC}(\mathrm{PM})$, especially at low operating temperatures. The polarization resistances of $\mathrm{Ni}-\mathrm{YSZ}$ and $\mathrm{Ni}-\mathrm{GDC}(\mathrm{PM})$ were almost the same at $900^{\circ} \mathrm{C}$ and $1000^{\circ} \mathrm{C}$ in 
both $\mathrm{H}_{2}$ and $\mathrm{NH}_{3}$ fuels. The difference in anodic polarization resistance for $\mathrm{Ni}-\mathrm{GDC}(\mathrm{PM})$ and $\mathrm{Ni}-\mathrm{YSZ}$ is larger in $\mathrm{NH}_{3}$ fuel than in $\mathrm{H}_{2}$ fuel at $600-800^{\circ} \mathrm{C}$. In the temperature range of $900-1000^{\circ} \mathrm{C}$, ammonia completely decomposed to produce $\mathrm{H}_{2}$ with the similar concentration to that in $\mathrm{H}_{2}$ fuel gas mixture in the present experimental condition. On the other hand, ammonia decomposed partially at $600-800^{\circ} \mathrm{C}$. The deviation of the polarization resistance between $\mathrm{NH}_{3}$ and $\mathrm{H}_{2}$ fuels is obviously small for $\mathrm{Ni}-\mathrm{GDC}(\mathrm{PM})$ even in the low temperature range, whereas the polarization resistance of Ni-YSZ in $\mathrm{NH}_{3}$ was very large. This tendency indicates that $\mathrm{Ni}-\mathrm{GDC}(\mathrm{PM})$ is a more appropriate catalyst for $\mathrm{NH}_{3}-$ fueled SOFCs than Ni-YSZ.

It was found that the limiting current was easily observed for a dilute ammonia fuel. This means that hydrogen formed by the partial decomposition of ammonia can be consumed by the electrochemical reaction. Therefore, the effect of ammonia concentration on the limiting current density was investigated to estimate the $\mathrm{NH}_{3}$ conversion on the cermet. It was assumed that the concentration of hydrogen produced on the cermet corresponds to the limiting current of the cell. A dilute fuel gas mixture of $x \% \mathrm{NH}_{3}-0.5 \% \mathrm{H}_{2} \mathrm{O}-(99.5-x) \% \mathrm{Ar}\left(x=0.3-0.9\right.$, flow rate; $\left.100 \mathrm{ml} \mathrm{min} \mathrm{m}^{-1}\right)$ was supplied to $\mathrm{Ni}-\mathrm{YSZ}$ and $\mathrm{Ni}-\mathrm{GDC}$ anodes at $700-1000^{\circ} \mathrm{C}$ to estimate the hydrogen concentration produced via ammonia decomposition from the limiting current. The hydrogen concentration was calculated by using following equations;

$$
i_{\text {limiting }}=n F\left(\frac{d N}{d t}\right)
$$


where $i_{\text {limiting }}$ is the limiting current (A), $d N / d t$ is the rate of the electrochemical reaction $\left(\mathrm{mol} \mathrm{s}^{-1}\right)$ which reflects the number of mole of hydrogen produced from ammonia decomposition, $n$ is the number of electrons transferred for the hydrogen oxidation, and $F$ is the Faraday's constant.

$$
C\left(\mathrm{H}_{2} \text { produced }\right) / \%=\left(\frac{d N / d t}{n_{\mathrm{t}}}\right) \times 100
$$

where $C\left(\mathrm{H}_{2}\right.$ produced $) / \%$ is the hydrogen concentration produced by ammonia decomposition reaction calculated from the limiting current, and $n_{\mathrm{t}}$ is the total number of moles of outlet gases (mol $\mathrm{s}^{-1}$ ) which are unreacted $\mathrm{NH}_{3}, \mathrm{H}_{2}, \mathrm{~N}_{2}, \mathrm{H}_{2} \mathrm{O}$, and $\mathrm{Ar}$.

Figure 4 shows current-voltage $(I-V)$ characteristics of single cells employing Ni-YSZ and $\mathrm{Ni}-\mathrm{GDC}(\mathrm{PM})$ anodes at $700^{\circ} \mathrm{C}$ and $1000^{\circ} \mathrm{C}$ with feeding humidified $\mathrm{NH}_{3}$. The $I-V$ curves for both cells were almost identical at $1000^{\circ} \mathrm{C}$, while at $700^{\circ} \mathrm{C}$ the cell with $\mathrm{Ni}-\mathrm{YSZ}$ and $\mathrm{Ni}-\mathrm{GDC}$ anodes reached to the limiting current of $c a .30$ and $100 \mathrm{~mA} \mathrm{~cm}{ }^{-2}$, respectively. The hydrogen concentration produced from ammonia decomposition over anodes estimated from the limiting current is depicted in Fig. 5(a) as a function of temperature. At $1000^{\circ} \mathrm{C}$ the hydrogen concentration was almost the same for both anodes because ammonia was completely decomposed in this temperature range. Below $800^{\circ} \mathrm{C}$, the hydrogen concentration for the Ni-YSZ anode was significantly lowered as compared with that for the Ni-GDC (PM) anode. This tendency corresponds to the fact that $\mathrm{Ni}-\mathrm{GDC}(\mathrm{PM})$ is more active 
for $\mathrm{NH}_{3}$ decomposition in this temperature region. Thus, the high catalytic activity for ammonia decomposition of Ni-GDC (PM) is favorable. Furthermore, the hydrogen concentration in the vicinity of the anode was highly affected by the ammonia concentration in the fuel gas mixture and the anode material (see Fig. 5(b)); the hydrogen concentration raised by increasing the ammonia concentration, and the conversion level was obviously higher for Ni-GDC (PM) anode.

\subsection{Effect of preparation method for Ni-GDC}

Further enhancement of anode performance for the direct $\mathrm{NH}_{3}$-fueled $\mathrm{SOFC}$ was investigated by preparing a fine powder of $\mathrm{Ni}-\mathrm{GDC}$ with large surface area [41]. It is expected that the activity for ammonia decomposition changes with the microstructure which is affected by the preparation method of the Ni-based cermet. Therefore, the Ni-GDC cermet was prepared through the glycine nitrate combustion route. The catalytic activity of $\mathrm{Ni}-\mathrm{GDC}(\mathrm{GN})$ for ammonia decomposition was higher than that of $\mathrm{Ni}-\mathrm{GDC}(\mathrm{PM})$ in the temperature range of $450-600^{\circ} \mathrm{C}$ as shown in Fig. 6 . The anodic overpotential in wet $\mathrm{H}_{2}$ demonstrated no significant difference between two Ni-GDC cermets from different preparation routs. On the other hand, the anodic overpotential of $\mathrm{Ni}-\mathrm{GDC}(\mathrm{GN})$ in wet $\mathrm{NH}_{3}$ was lower than that of $\mathrm{Ni}-\mathrm{GDC}(\mathrm{PM})$ at $600^{\circ} \mathrm{C}$ (see Fig. 7(a) and (b)). This led to the performance enhancement of the cell with $\mathrm{Ni}-\mathrm{GDC}(\mathrm{GN})$ anode due to higher catalytic activity for ammonia decomposition. The anodic polarization resistance for $\mathrm{Ni}-\mathrm{GDC}$ (GN) was significantly lower in ammonia at 600 and $700^{\circ} \mathrm{C}$ than that for $\mathrm{Ni}-\mathrm{GDC}(\mathrm{PM})$, while that in hydrogen was almost 
comparable to each other (see Fig. 7(c) and (d)). The high catalytic activity of Ni-GDC (GN) for ammonia decomposition led to an increase in a hydrogen concentration in the vicinity of the anode, resulting in the high cell performance. The BET surface area for Ni-YSZ, Ni-GDC (PM), and $\mathrm{Ni}-\mathrm{GDC}(\mathrm{GN})$ was $0.6,0.7$, and $1.3 \mathrm{~m}^{2} \mathrm{~g}^{-1}$, respectively. Every cermet possessed the relatively small surface area after calcination at $1400^{\circ} \mathrm{C}$ for $5 \mathrm{~h}$ and subsequent reduction at $1000^{\circ} \mathrm{C}$ in hydrogen. However, the surface area of Ni-GDC (GN) was twice as that of Ni-GDC (PM). This indicates that the high activity of Ni-GDC (GN) is ascribed to the large surface area. Therefore, Ni-GDC prepared by the glycine nitrate process is preferable for direct $\mathrm{NH}_{3}-$ fueled SOFCs.

Furthermore, the microstructure of Ni-YSZ, Ni-GDC (PM), and Ni-GDC (GN) was observed by SEM (see Fig. 8). A secondary electron detector and an in-lens detector were effective in observing the topographic image and in distinguishing Ni metal (bright particles) and oxide component (dark particles), respectively. In the case of $\mathrm{Ni}-\mathrm{YSZ}, \mathrm{Ni}$ metal aggregated to form large particles which were not dispersed well as in the case of Ni-GDC (PM) and Ni-GDC (GN). For Ni-GDC cermets, the ceria network prevented aggregation of $\mathrm{Ni}$ particles. The small particle size of Ni metal in the Ni-GDC (GN) anode led to the high ammonia decomposition activity, the abundant triple-phase boundary (TPB), and an increase in the rate of electrochemical oxidation of hydrogen produced from ammonia decomposition. 


\section{Conclusions}

In this study the comparison of catalytic activities of $\mathrm{Ni}-\mathrm{YSZ}$ and $\mathrm{Ni}-\mathrm{GDC}$ revealed that the $\mathrm{Ni}-\mathrm{GDC}$ cermet demonstrated higher activity for ammonia decomposition than Ni-YSZ. Doped-ceria possessed a large number of basic sites on its surface which were favourable for ammonia conversion.

The anodic polarization resistance of $\mathrm{Ni}-\mathrm{GDC}$ anode in $\mathrm{NH}_{3}$ was smaller than that of $\mathrm{Ni}-\mathrm{YSZ}$ at $600^{\circ} \mathrm{C}$. The hydrogen concentration estimated from the limiting current for ammonia fuel was higher for Ni-GDC than for Ni-YSZ. The results revealed that the SOFC performance was enhanced by using Ni-GDC anode because of the mixed ionic-electronic conductivity of GDC under reducing atmospheres and high catalytic activity for ammonia decomposition. Moreover, the contribution of preparation method of anode material for the ammonia catalytic decomposition and the cell performance was investigated. The cell performance was enhanced by using Ni-GDC prepared through the glycine-nitrate combustion route because of a good distribution of the small Ni particles within anode microstructure which led to the extension of the triple-phase boundary (TPB) and the enhancement of the electrochemical oxidation of hydrogen produced from ammonia decomposition. 


\section{Acknowledgment}

This work was supported by Council for Science, Technology and Innovation (CSTI), Cross-ministerial Strategic Innovation Promotion Program (SIP), "energy carrier" (Funding agency:

JST). 


\section{References}

[1] P. E. Dodds, I. Staffell, A. D. Hawkes, F. Li, P. Grunewald, W. McDowall, P. Ekins, Int. J. Hydrogen Energy 40 (2015) 2065-2083.

[2] MC. Williams, FuelCells 1 (2001) 87-91.

[3] F. Zink, Y. Lu, L. Schaefer, Energ. Convers. Manage. 48(2007) 809-818.

[4] R.A. George, J. Power Sources 86 (2000) 134-139.

[5] C. J. Winter, Int. J. Hydrogen Energy 34 (2009) S1-S52.

[6] T.N. Veziroglu, Int. Scien. J. for Alternative Energy and Ecology 4 (2007) 29-39.

[7] J.O. Jensen, A.P. Vestbo, Q. Li,N.J. Bjerrum, J. of Alloys and Compounds 446-447 (2007) 723-728.

[8] A.S. Chellappa, C.M. Fischer, W.J. Thomson, Appl. Catal. A-Gen. 227 (2002) 231-240.

[9] L. Zhang, Y. Cong, W. Yang, L. Lin, Chinese J Catal. 28 (2007) 749-751.

[10] C. Zamfirescu, I. Dincer, J. Power Sources 185 (2008) 459-465.

[11] G. Cinti, U. Desideri, D. Penchini,G. Discepoli, Fuel Cells 14 (2014) 221-230.

[12] C. H. Christensen, T. Johannessen, R. Z. Sørensen, J. K. Nørskov, Catal. Today 111 (2006) 140-144.

[13] F. Ishak, I. Dincer, C. Zamfirescu, J. Power Sources 202 (2012) 157-165.

[14] A. Wojcik, H. Middleton, I. Damopoulos, J. V. herle, J. Power Sources 118 (2003) 342-348.

[15] G.G.M. Fournier, I.W. Cumming, K. Hellgardt, J. Power Sources 162 (2006) 198-206.

[16] M. Qianli, M. Jianjun, S. Zhou, Y. Ruiqiang, G. Jianfeng, G. Meng, J. Power Sources 164 (2007) 86-89. 
[17] L. Liu, K. Sun , X. Wu, X. Li, M. Zhang, N. Zhang, X. Zhou, int. J. Hydrogen Energy 37 (2012) $10857-10865$.

[18] Q. Ma, R. Peng, L. Tian, G. Meng, Electrochem. Comm. 8 (2006) 1791-1795.

[19] L. Pelletier, A. McFarlan, N. Maffei, J. Power Sources 145 (2005) 262-265.

[20] N. Maffei, L. Pelletier, J.P. Charland, A. M. Farlan, J. Power Sources 140 (2005) 264-267.

[21] N. Maffei, L. Pelletier, J.P. Charland , A. M. Farlan, J. Power Sources 162 (2006) 165-167.

[22] N. Maffei, L. Pelletier, A. M. Farlan, J. Power Sources 175 (2008) 221-225 (2008).

[23] Q. Ma, R. Peng, Y. Lin, J. Gao, G. Meng, J. Power Sources 161 (2006) 95-98.

[24] A. F. S. Molouk, T. Okanishi, H. Muroyama, T. Matsui, K. Eguchi, J. Electrochem. Soc. 162 (2015) F1268-F1274.

[25] S.P. Jiang, P.J. Callus , S.P.S. Badwal, Solid State Ionics 132 (2000) 1-14.

[26] H.J. Cho, G.M. Choi, J. Power Sources 176 (2008) 96-101.

[27] W. Ana, D. Gatewoodb, B. Dunlapb, C. Heath Turner, J. Power Sources 196 (2011) 4724-4728.

[28] M. Marinsek, K. Zupan, J. Macek, J. Power Sources 86 (2000) 383-389.

[29] D.H. Prasad, H.I. Ji, H.R. Kim, J.W. Son, B.K. Kim, H.W. Lee, J.H. Lee, Appl. Catal. B-Environ. 101 (2011) 531-539.

[30] S. Souentie, M. Athanasiou, D.K. Niakolas, A. Katsaounis, S.G. Neophytides, C.G. Vayenas, J.Catal. 306 (2013) 116-128.

[31] S. Zha, W. Rauch, M. Liu, Solid State Ionics 166 (2004) 241-250. 
[32] C. Fu, S. H. Chan, Q. Liu, X. Ge, G. Pasciak, Int. J. Hydrogen Energy 35 (2010) 301-307.

[33] T. Matsui R. Kishida, J. Kim, H., K. Eguchi, J. Electrochem. Soc. 157 (2010) B776-B781.

[34] J. Yang, T. Akagi, T. Okanishi, H. Muroyama, T. Matsui, K. Eguchi, Fuel Cells 15 (2015) 390-397.

[35] M.C.J. Bradford, P.E. Fanning, M.A. Vannice, J. Catal. 172 (1997) 479-484.

[36] D.G. Löffler, L.D. Schmidt, J. Catal. 41 (1976) 440-454.

[37] W. Tsai, W.H.Weinberg, J. Phys. Chem. 91 (1987) 5302-5307.

[38] K. Aika, J. Kubota, Y. Kadowaki, Y. Niwa, Y. Izumi, Appl. Surf. Sci. 121/122 (1997) 488-491.

[39] S. F. Yin, Q. H. Zhang, B. Q. Xu, W. X. Zhu, C. F. Ng, C. T. Au, J. Catal. 224 (2004) 384-396.

[40] J. Yang, A. F. S. Molouk, T. Okanishi, H. Muroyama, T. Matsui, K. Eguchi, ACS Appl. Mater. Interfaces 7 (2015) 7406-7412.

[41] S. Zha, W. Rauch, M. Liu, Solid State Ionics 166 (2004) 241-250. 


\section{Figure captions}

Fig. 1 Schematic diagram of the preparation routes for Ni-YSZ and Ni-GDC cermets.

Fig. 2 (a) Ammonia conversion over Ni-YSZ, Ni-GDC (PM), YSZ, and GDC as a function of catalyst temperature. Reaction condition; $66.7 \% \mathrm{NH}_{3}-33.3 \% \mathrm{Ar}$, gas space velocity $=60001 \mathrm{~kg}^{-1} \mathrm{~h}^{-1}$. (b) Temperature programmed desorption of $\mathrm{CO}_{2}\left(\mathrm{CO}_{2}-\mathrm{TPD}\right)$ for $\mathrm{YSZ}$ and GDC.

Fig. 3 Impedance spectra at $600^{\circ} \mathrm{C}$ and $1000^{\circ} \mathrm{C}$ in wet $\mathrm{H}_{2}$ and $\mathrm{NH}_{3}$ fuel (a-d) and anodic polarization resistance in wet (e) $\mathrm{H}_{2}$ and (f) $\mathrm{NH}_{3}$ fuel at $600-1000^{\circ} \mathrm{C}$ for $\mathrm{Ni}-\mathrm{YSZ}$ and $\mathrm{Ni}-\mathrm{GDC}$ (PM) anodes.

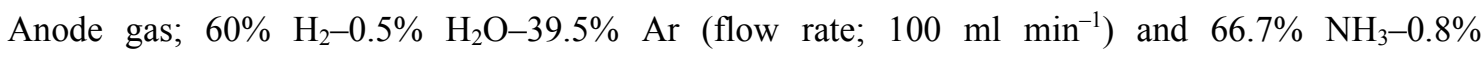

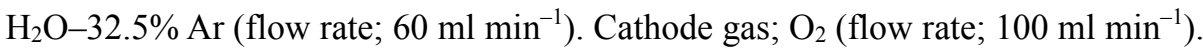

Fig. $4 I-V$ curves for the cell of Ni-YSZ|YSZ|LSM and Ni-GDC (PM)|YSZ|LSM at (a) $1000^{\circ} \mathrm{C}$ and

(b) $700^{\circ} \mathrm{C}$. Anode gas; $0.7 \% \mathrm{NH}_{3}-0.5 \% \mathrm{H}_{2} \mathrm{O}-98.8 \% \mathrm{Ar}$ (flow rate; $100 \mathrm{ml} \mathrm{min}{ }^{-1}$ ). Cathode gas; $\mathrm{O}_{2}$ (flow rate; $100 \mathrm{ml} \mathrm{min}^{-1}$ ).

Fig. $5 \mathrm{H}_{2}$ concentration produced from ammonia decomposition at the limiting current as a function of (a) temperature and (b) ammonia concentration. Anode gas; $x \% \mathrm{NH}_{3}-0.5 \% \mathrm{H}_{2} \mathrm{O}-(99.5-x) \% \mathrm{Ar}(x=$

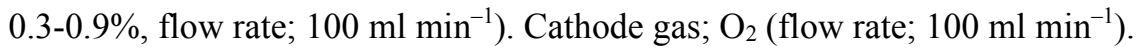


Fig. 6 Ammonia conversion over $\mathrm{Ni}-\mathrm{GDC}(\mathrm{PM})$ and $\mathrm{Ni}-\mathrm{GDC}(\mathrm{GN})$ as a function of catalyst temperature. Reaction condition; $66.7 \% \mathrm{NH}_{3}-33.3 \% \mathrm{Ar}$, gas space velocity $=60001 \mathrm{~kg}^{-1} \mathrm{~h}^{-1}$.

Fig. 7 Anodic overpotential in wet (a) $\mathrm{H}_{2}$ and (b) $\mathrm{NH}_{3}$ fuel at $600^{\circ} \mathrm{C}$ and anodic polarization resistance in wet (c) $\mathrm{H}_{2}$ and (d) $\mathrm{NH}_{3}$ fuel at $600-1000^{\circ} \mathrm{C}$ for $\mathrm{Ni}-\mathrm{GDC}(\mathrm{PM})$ and $\mathrm{Ni}-\mathrm{GDC}(\mathrm{GN})$. Anode gas; $60 \%$ $\mathrm{H}_{2}-0.5 \% \mathrm{H}_{2} \mathrm{O}-39.5 \% \mathrm{Ar}$ (flow rate; $100 \mathrm{ml} \mathrm{min}^{-1}$ ) and $66.7 \% \mathrm{NH}_{3}-0.8 \% \mathrm{H}_{2} \mathrm{O}-32.5 \%$ Ar (flow rate;

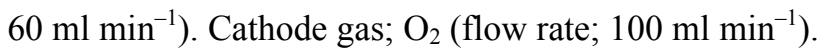

Fig. 8 Cross-sectional images of (a) Ni-YSZ, (b) Ni-GDC (PM), and (c) Ni-GDC (GN) anode obtained by a secondary electron detector (left images) and an in-lens detector (right images); bright particle Ni; dark phase YSZ or GDC. 


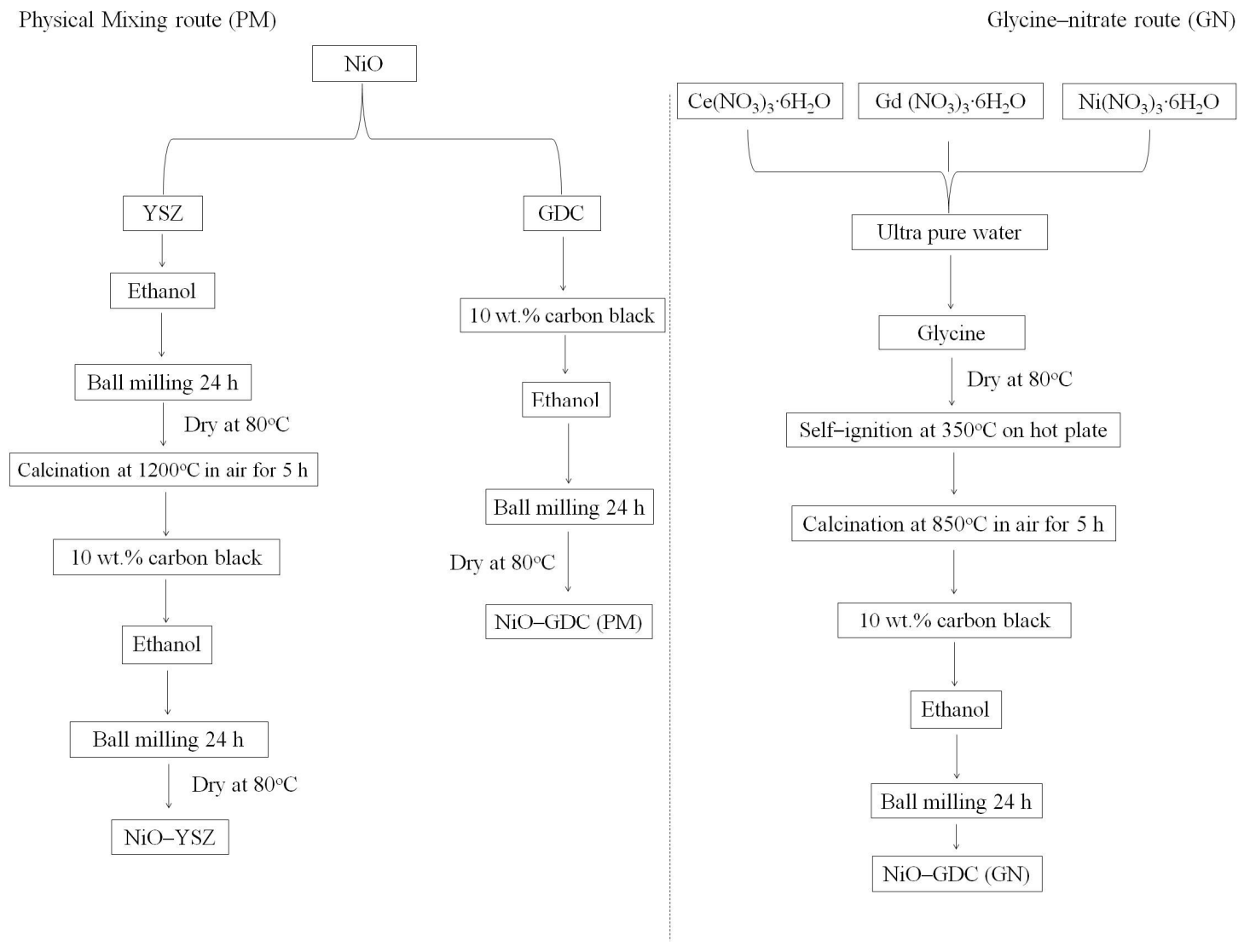

Fig. 1 Schematic diagram of the preparation routes for Ni-YSZ and Ni-GDC.

Fig. 1 A. F. S. Molouk et al. 

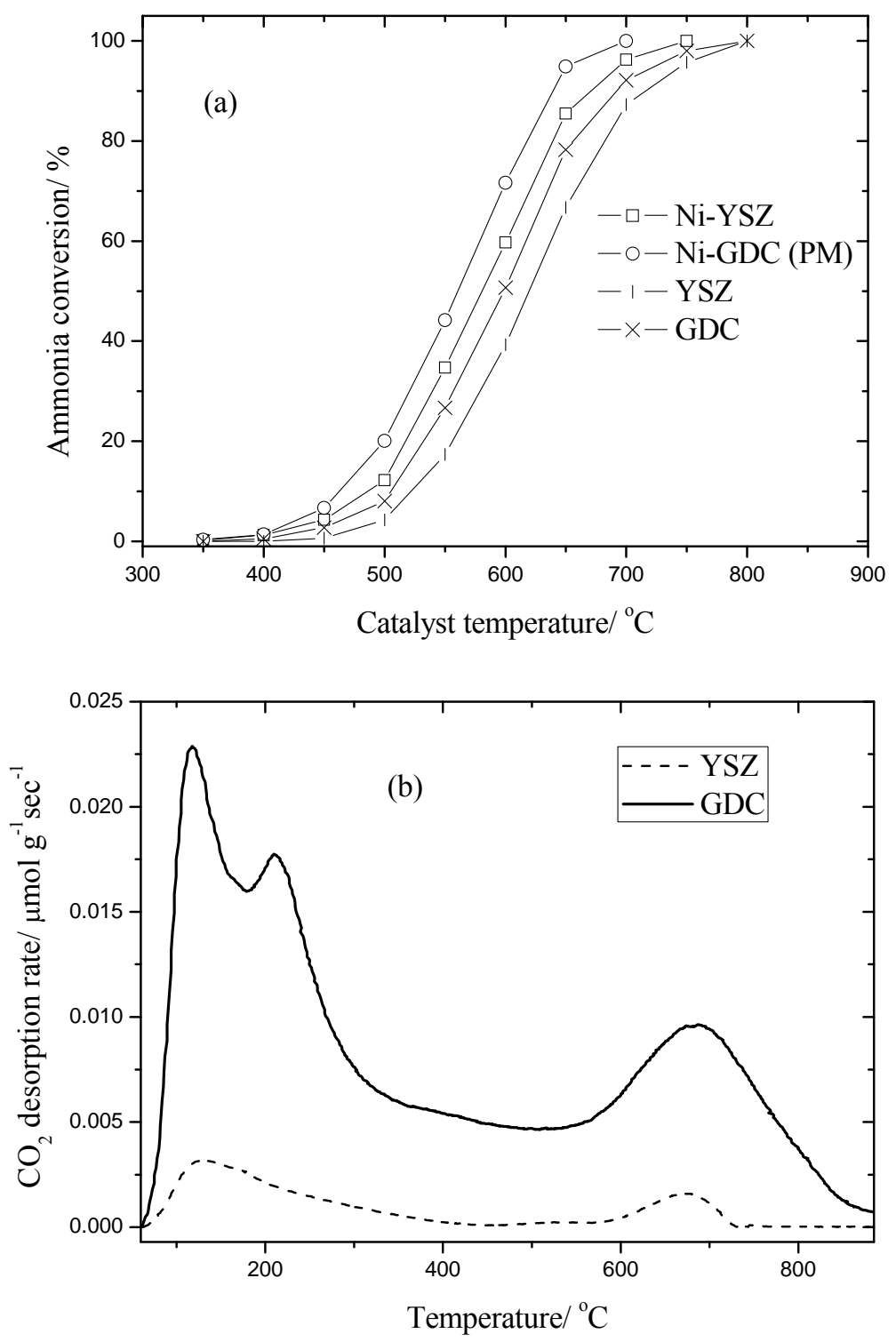

Fig. 2 (a) Ammonia conversion over Ni-YSZ, Ni-GDC (PM), YSZ, and GDC as a function of catalyst temperature. Reaction condition; $66.7 \% \mathrm{NH}_{3}-33.3 \% \mathrm{Ar}$, gas space velocity $=60001 \mathrm{~kg}^{-1} \mathrm{~h}^{-1}$. (b) Temperature programmed desorption of $\mathrm{CO}_{2}\left(\mathrm{CO}_{2}-\mathrm{TPD}\right)$ for $\mathrm{YSZ}$ and GDC.

Fig. 2 A. F. S. Molouk et al. 

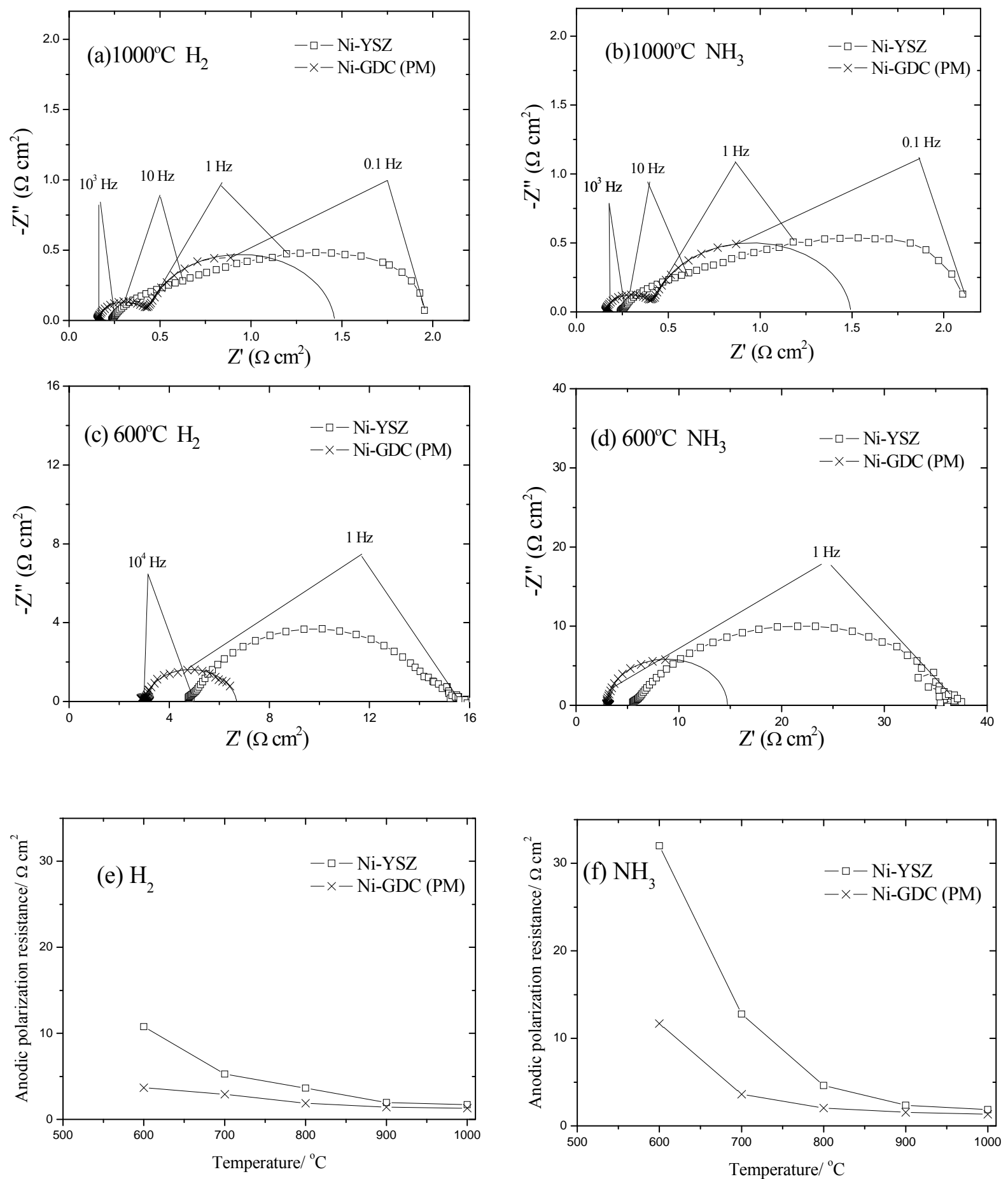

Fig. 3 Impedance spectra at $600^{\circ} \mathrm{C}$ and $1000^{\circ} \mathrm{C}$ in wet $\mathrm{H}_{2}$ and $\mathrm{NH}_{3}$ fuel (a-d) and anodic polarization resistance in wet (e) $\mathrm{H}_{2}$ and (f) $\mathrm{NH}_{3}$ fuel at $600-1000^{\circ} \mathrm{C}$ for $\mathrm{Ni}-\mathrm{YSZ}$ and $\mathrm{Ni}-\mathrm{GDC}$ (PM) anodes.

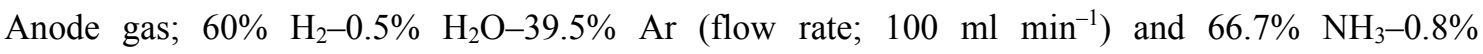
$\mathrm{H}_{2} \mathrm{O}-32.5 \% \mathrm{Ar}$ (flow rate; $60 \mathrm{ml} \mathrm{min}^{-1}$ ). Cathode gas; $\mathrm{O}_{2}$ (flow rate; $100 \mathrm{ml} \mathrm{min}^{-1}$ ).

Fig. 3 A. F. S. Molouk et al 

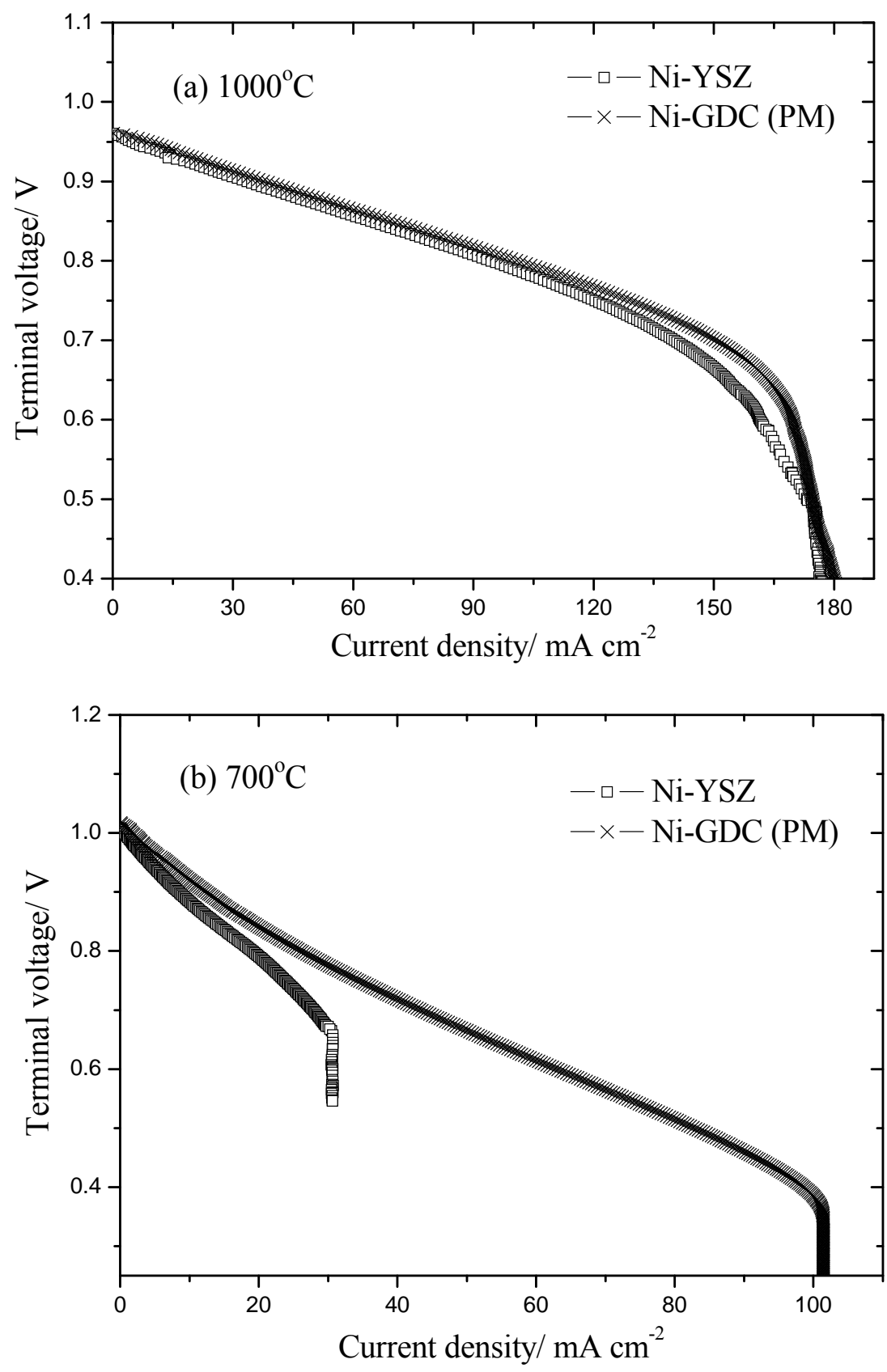

Fig. $4 I-V$ curves for the cell of Ni-YSZ|YSZ|LSM and Ni-GDC (PM)|YSZ|LSM at (a) $1000^{\circ} \mathrm{C}$ and (b) $700^{\circ} \mathrm{C}$. Anode gas; $0.7 \% \mathrm{NH}_{3}-0.5 \% \mathrm{H}_{2} \mathrm{O}-98.8 \%$ Ar (flow rate; $100 \mathrm{ml} \mathrm{min}{ }^{-1}$ ). Cathode gas; $\mathrm{O}_{2}$

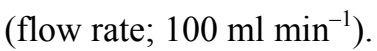

Fig. 4 A. F. S. Molouk et al. 

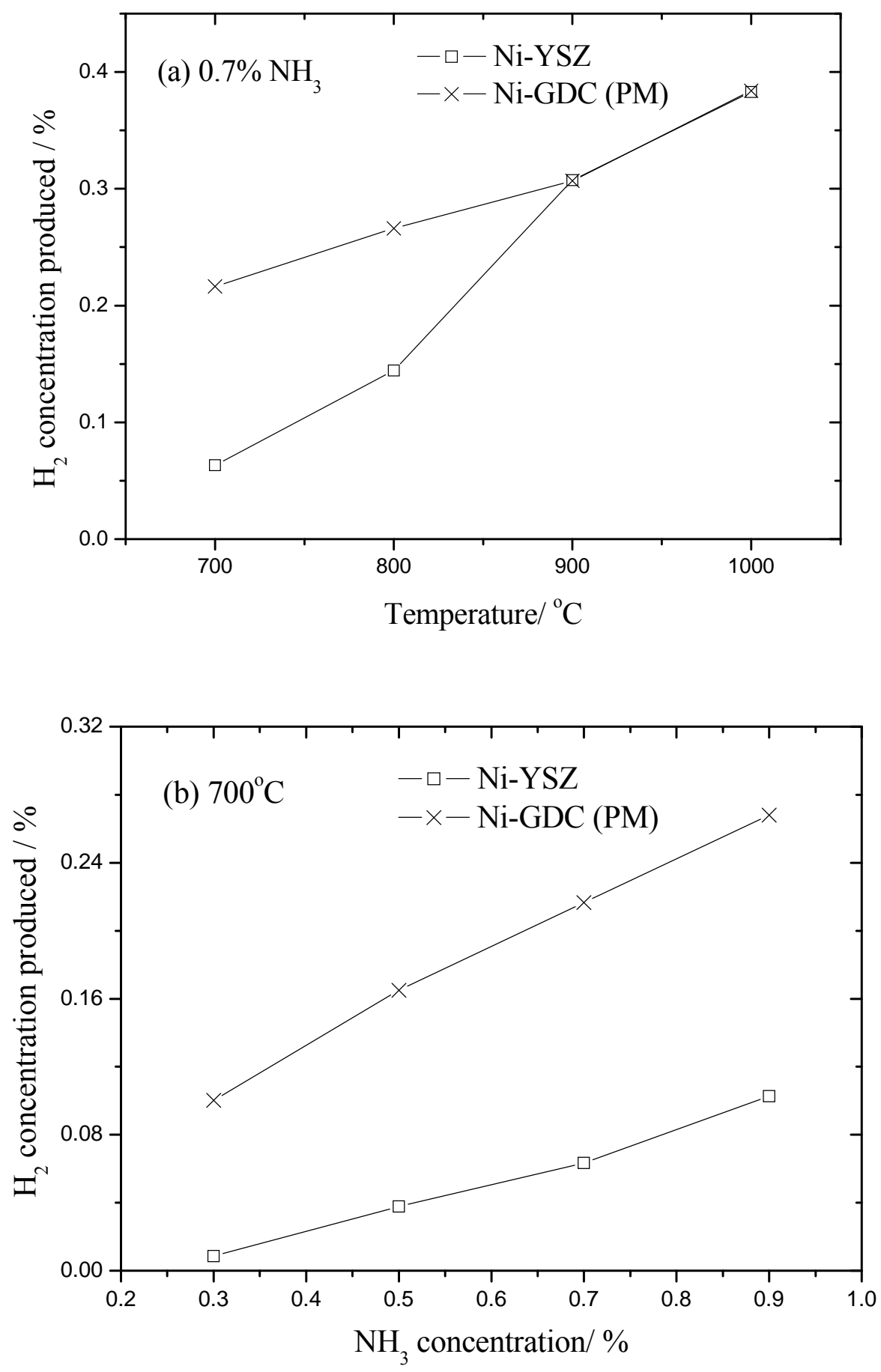

Fig. $5 \mathrm{H}_{2}$ concentration produced from ammonia decomposition at the limiting current as a function of (a) temperature and (b) ammonia concentration. Anode gas; $x \% \mathrm{NH}_{3}-0.5 \% \mathrm{H}_{2} \mathrm{O}-(99.5-x) \% \mathrm{Ar}(x=$

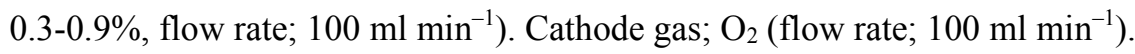

Fig. 5 A. F. S. Molouk et al. 


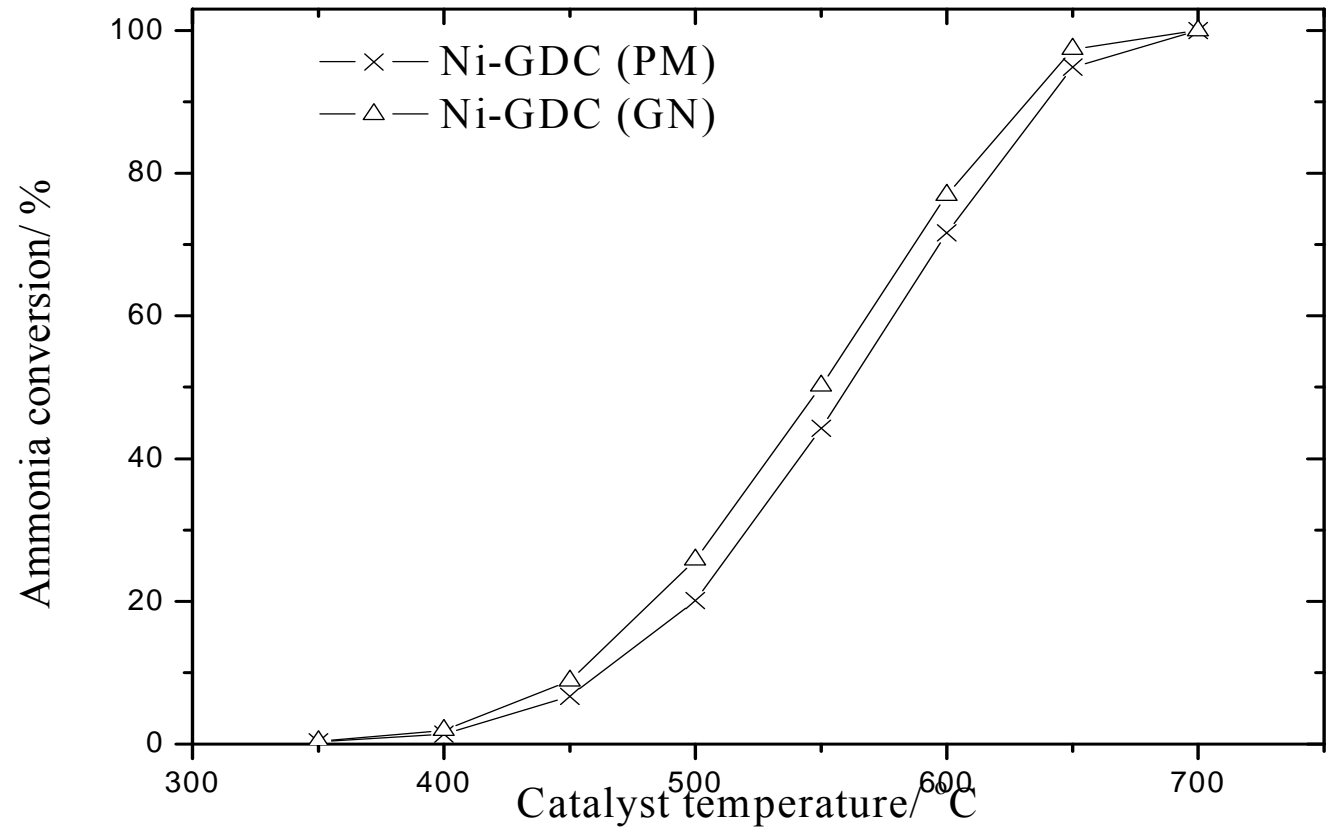

Fig. 6 Ammonia conversion over Ni-GDC (PM) and Ni-GDC (GN) as a function of catalyst temperature. Reaction condition; $66.7 \% \mathrm{NH}_{3}-33.3 \% \mathrm{Ar}$, gas space velocity $=60001 \mathrm{~kg}^{-1} \mathrm{~h}^{-1}$.

Fig. 6 A. F. S. Molouk et al. 

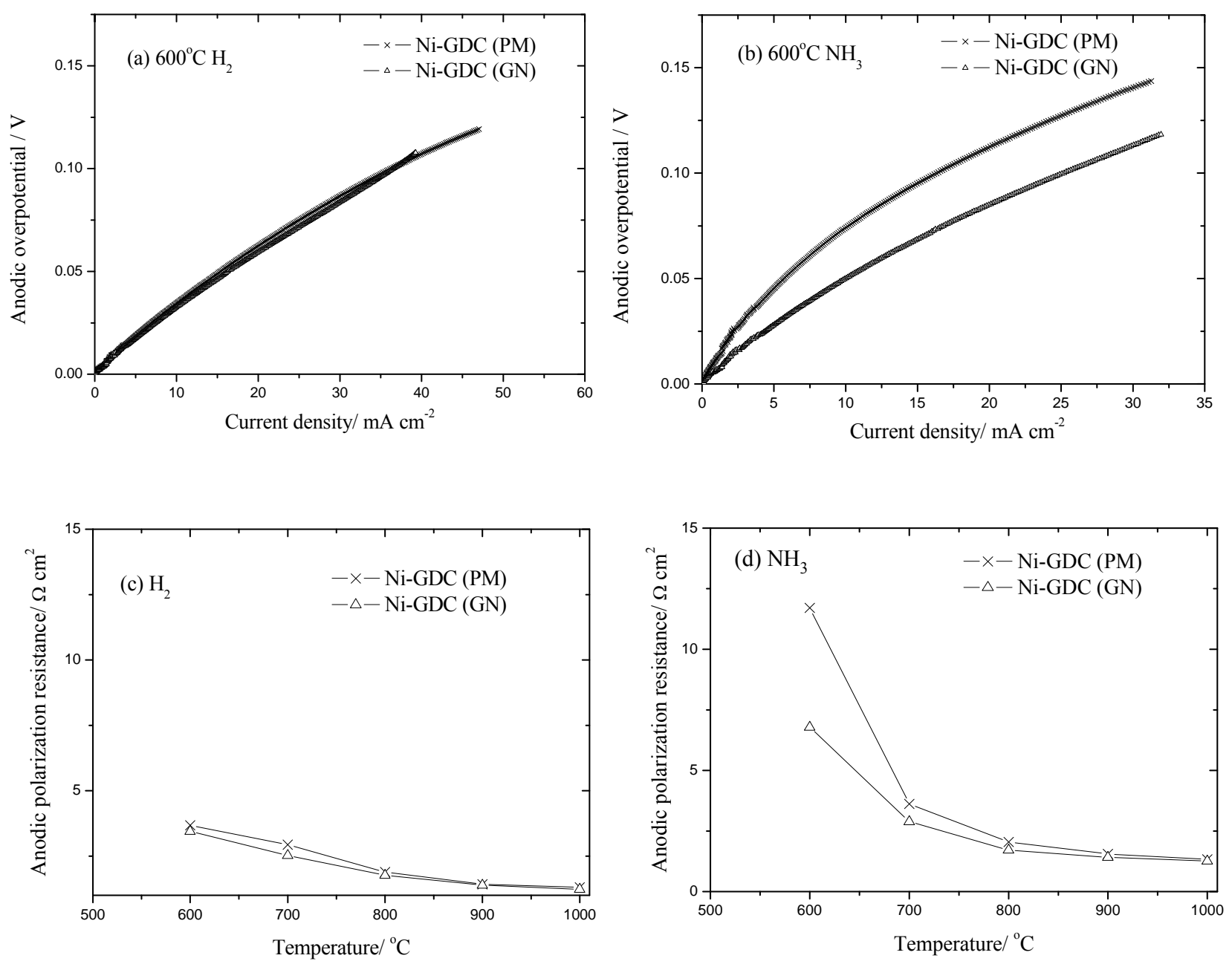

Fig. 7 Anodic overpotential in wet (a) $\mathrm{H}_{2}$ and (b) $\mathrm{NH}_{3}$ fuel at $600^{\circ} \mathrm{C}$ and anodic polarization resistance in wet (c) $\mathrm{H}_{2}$ and (d) $\mathrm{NH}_{3}$ fuel at $600-1000^{\circ} \mathrm{C}$ for $\mathrm{Ni}-\mathrm{GDC}$ (PM) and $\mathrm{Ni}-\mathrm{GDC}(\mathrm{GN})$. Anode gas; $60 \%$ $\mathrm{H}_{2}-0.5 \% \mathrm{H}_{2} \mathrm{O}-39.5 \% \mathrm{Ar}$ (flow rate; $100 \mathrm{ml} \mathrm{min}^{-1}$ ) and $66.7 \% \mathrm{NH}_{3}-0.8 \% \mathrm{H}_{2} \mathrm{O}-32.5 \%$ Ar (flow rate; $60 \mathrm{ml} \mathrm{min}{ }^{-1}$ ). Cathode gas; $\mathrm{O}_{2}$ (flow rate; $100 \mathrm{ml} \mathrm{min}^{-1}$ ).

Fig. 7 A. F. S. Molouk et al. 
(a)
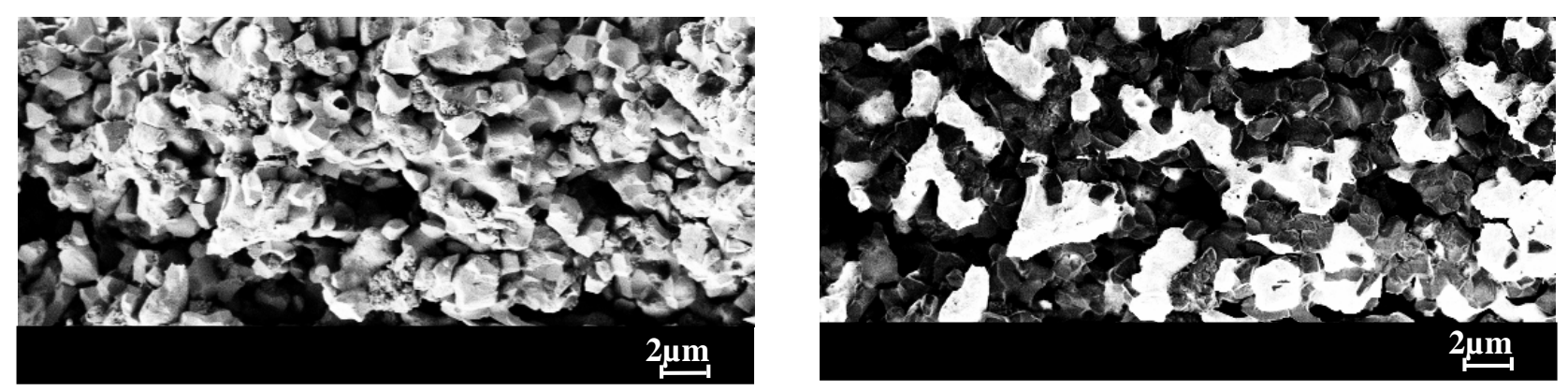

(b)
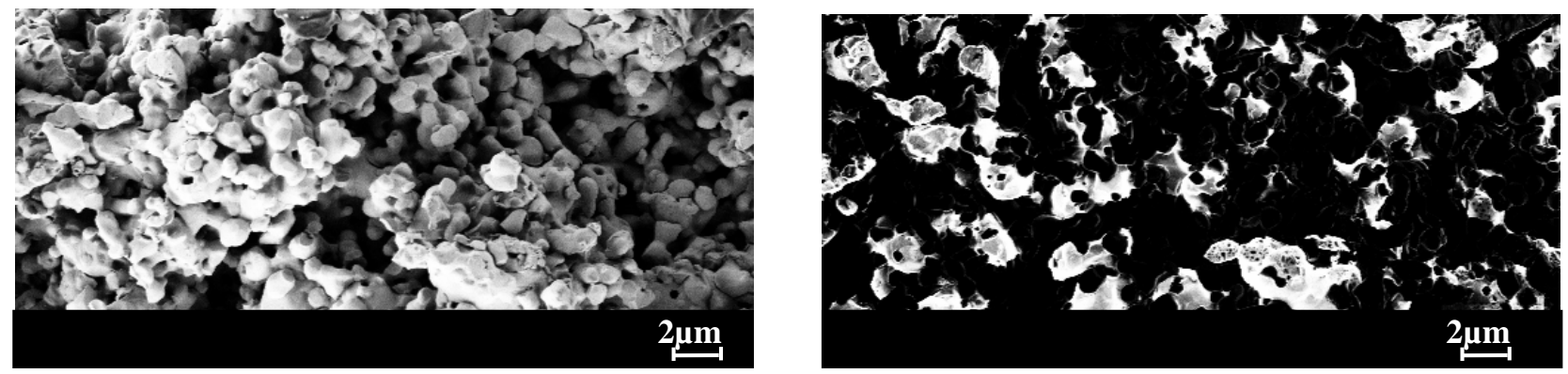

(c)
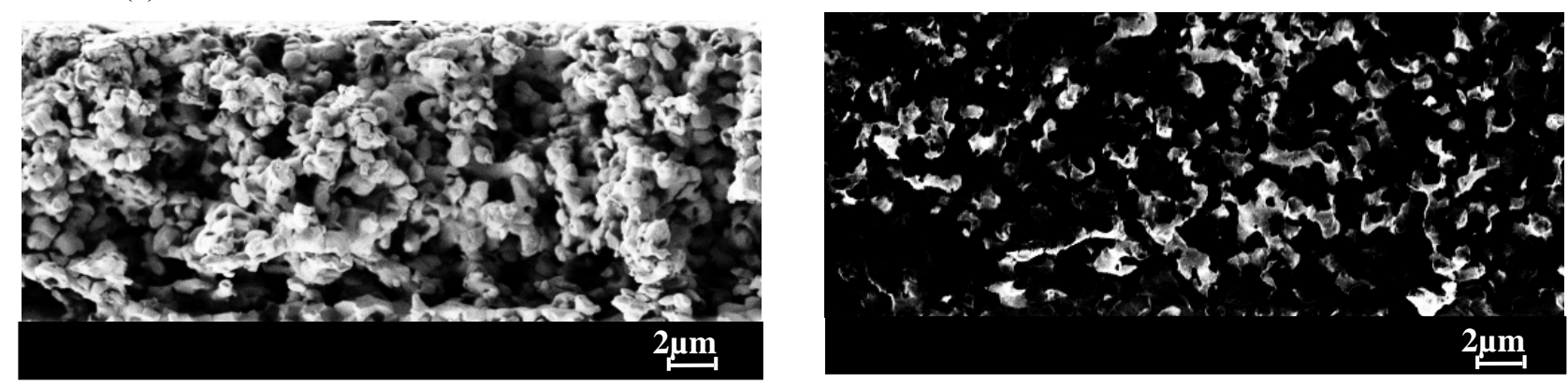

Fig. 8 Cross-sectional images of (a) Ni-YSZ, (b) Ni-GDC (PM), and (c) Ni-GDC (GN) anode obtained by a secondary electron detector (left images) and an in-lens detector (right images); bright particle Ni; dark phase YSZ or GDC.

Fig. 8 A. F. S. Molouk et al. 